\title{
The emancipation of the equine veterinary practitioner in the Netherlands
}

\author{
Joop B. A. Loomans, Peter. A. Koolmees', Ab Barneveld and René P. van Weeren \\ Department of Equine Sciences, Faculty of Veterinary Medicine and Institute for Risk Assessment Sciences ${ }^{1}$, Faculty of Veterinary Medicine, Utrecht University, the \\ Netherlands
}

\begin{abstract}
Summary
Equitation is becoming more and more popular in western countries. Leisure horses populate former agricultural lands and the number of professional training stables, stud farms and riding schools has increased dramatically in recent years. In the Netherlands the annual turnover in the equine industry is estimated at 2 billion Euros and is still growing. The horse has conquered an important position in the hearts and minds of many young girls and (to a lesser extend) boys. The fascination for the horse is certainly not limited to people with an equine or agricultural background, or to specific social classes. This paper puts this development in a historical perspective and describes the heyday of the former famous equine "horse masters", who were mainly associated with the cavalry, the decline of specific equine knowledge during the era of rapid mechanisation, and the revival of the horse vet as the modern equine veterinarian and equine specialist treating leisure and sport horses.
\end{abstract}

Keywords: history, veterinary profession, equine practitioner, emancipation, Netherlands

\section{Die Emanzipation der Pferdearztes in den Niederlanden}

Der Reitsport wird in den westlichen Ländern mehr und mehr populär. Freizeitpferde bevölkern ehemals landwirtschaftliche Flächen und die Zahl professioneller Trainigsställe, Gestüte und Reitschulen erhöhte sich in den letzten Jahren dramatisch. In den Niederlanden wird der Jahresumsatz der Pferdeindustrie auf 2 Milliarden Euro geschätz† mit zunehmender Tendenz. Das Pferd hat in den Herzen und Köpfen vielr jungen Mädchen und in geringerem Maße auch der Jungen einen wichtigen Platz erobert. Die Faszination für das Pferd ist zweifellos nicht auf Menschen mit landwirtschaftlichem Hintergrund oder auf spezielle soziale Klassen beschränkt. Der vorliegenden Artikel stellt die Entwicklung in einen historischen Zusammenhang und beschreibł die Blütezeit der berühmten Stallmeister früherer Zeiten, die überwiegend mit der Kavallerie verbunden waren, den Niedergang der Pferdekenntnis während der Ära der Mechanisierung und die Wiedergeburt des Pferdearztes als modernen Tiermedizininer und Fachtierarzt für Freizeit- und Sportpferde.

Schlüsselwörter: Geschichte, Berufstand, Tierarzt, Pferdearzt, Entwicklung, Niederlande

\section{Introduction}

The development of a profession is a dynamic process. According to sociological theories a profession is only established if three processes have taken place: 1) differentiation, 2) legitimation, 3) institutionalisation. With respect to the veterinary profession these processes have taken place and have given the veterinarian hiss present status (Koolmees 1992, Offringa 1983). Differentiation and specialisation within the veterinary profession are ongoing processes and in modern western society the equine veterinary practitioner is trying to define his own position within the total scope of veterinary medicine. In this paper the development from the ancient trade of "paardenmeester" (horse master) in the seventeenth century to the profession of equine veterinary practitioner today is described. In addition, the changing role of the horse and the related development of the market for equine veterinary services in the Netherlands are evaluated.

\section{The treatment of horses in the seventeenth and eigh- teenth century.}

One of the first comprehensive studies on the treatment of horses in the Netherlands was written by Pieter van Naald- wijck in the seventeenth century. Pieter van Naaldwijck studied philosophy, theology and medicine from 1614 until 1624 at Leyden University. During his study he already showed much interest in hippiatric writings. In 1624 he left for Gothenburg (Sweden) as a general physician, but at the same time became a manager of a brick factory. As a physician, he was also responsible for the horses used in the factory and of those needed for the construction of the harbour of Gothenburg. In 1631 he published a book in two volumes called Libri duo Philippicorum, sive de equorum natura, electione, educatione, disciplina et curatione [The horse friend: about the nature-, selection-, education-, training- and treatment of the horse] (van Naaldwijck 1631). It was considered to be one of the first scientific books on horses, based on own experiences and therapies, combined with information from ancient authors. In practice, however, most horses in his days were treated by empirically "educated" laymen. Farriers played an important role, as testified by the publication of Pieter Almanus van Cour, farrier and self proclaimed "equine veterinarian" from 1688: Toevlugt of Heylsame Remedien voor alderhande Siecktens en Accidenten die de Paerden soude konnen overkoomen [Curies and remedies for all kinds of diseases and injuries that might affect horses] (van Cour 1688). In 1769 the zoologist Johannes Le Franca van Berkhey published De Natuurlijke Historie van Holland (The natural history 
of Holland) in nine parts. Part four was mainly dedicated to the horse, indicating the importance of this species for the Dutch society at that moment. According to Le Francq van Berkhey, knowledge on health, reproduction, diseases and injuries of horses almost equalled the knowledge on human medicine at that time. His work shows that the small amount of scientific knowledge that was available on equine diseases and equitation was disseminated all over Europe and was also applied in daily life. However, he also speaks highly about farriers who, thanks to their expertise, empirical knowledge and "clinical look", sometimes obtained the status of "equine professor" amongst riding masters, stable owners and younger farriers (Le Franca van Berkhey 1769). Other contributors to equine veterinary care were so-called "paardenmeesters" (horse masters), who were mainly educated in the army and associated with the cavalry, farmers, stallion owners, castrators and also inspectors at equine markets who had to look for possible defects of horses offered for sale and in fact performed the eighteenth century version of the prepurchase examination.

\section{Treating horses for the military.}

From 1792 onward the horse masters were appointed to take care of the army's sick horses. They had the rank of noncommissioned officer. Only in 1807 the first equine veterinary officer in The Netherlands was appointed by Lovis Napoleon, a brother of the French emperor, who had installed him on the Dutch throne (Steltenpool 1996). When Louis Napoleon was confronted with a shortage of veterinarians in the northern part of his kingdom, he ordered the foundation of the so-called "Leidse Commissie" (Leyden committee), a "scientific" committee that assessed potential, experienced, "self made" veterinarians who had studied abroad, and appointed them as first and second class veterinarians (Offringa 1971, Wester 1939). After the French occupation and the battle at Waterloo, the veterinary care made part of the general medical care of the army and all potential army veterinarians had to be examined by the "Leidse Commissie". However, king William I insisted on an independent veterinary school for the education of skilled veterinarians, located in a city with a university that could provide a more scientific background. In 1821, the "Rijksveeartsenijschool" (State Veterinary School) was opened in Utrecht, funded by the Agricultural Fund. The first veterinarians left this school with a diploma in 1826 as veterinarians first or second class and the "Leidse Commissie" resigned. The first vets had a hard time since their practical skills were limited; they faced contagious pleuropneumonia and rinderpest and had no remedies. Their practical skills were limited due to the lack of patients and experienced veterinarians as teachers at the "Rijksveeartsenijschool". Farmers and horse owners were used to empirical medicine and quakkery as practiced by obstetricians, farriers, castrators and stable masters. The army however, did acknowledge the importance of these scientifically educated veterinarians, as did the government. After the secession of Belgium in 1830, many foreign-educated French speaking vets left the army, and, in order to maintain a fair amount of equine army vets, the army started to pay for the education of veterinarians (Offringa 1971, Wester 1939). For the acquisition of army horses ("remonteren") by the government strict rules were applied with initially only an advisory role for the equine veterinarian, but later on the first class equine veterinarians were given a more prominent role. The acquisition committee, for instance for artillery horses, consisted of a high-ranking cavalry officer, an artillery captain and an equine veterinarian first class, who was appointed by the ministry of war and nominated by the inspector of the artillery in conjunction with the inspector of the health services (Schimmel et al. 1895). After leaving the "Rijksveeartsenijschool", students who had been paid for by the Agricultural Fund were appointed by this fund that paid a part of their wages. They were not allowed to practice for themselves, but were sent to the countryside to combat contagious diseases. The students financed by the Ministry of War, however, had to serve the army for ten years, were wellpaid and were also allowed to practice veterinary medicine privately from 1841 onwards. Equine veterinarians thus became the new elite and many potential students applied. As a result of this, there was a selection procedure that involved exams on topics including French, German, English, Latin and Greek. It may not be surprising that three future teachers of the "Rijksveeartsenijschool" started their careers as equine veterinarians (Figure 1).

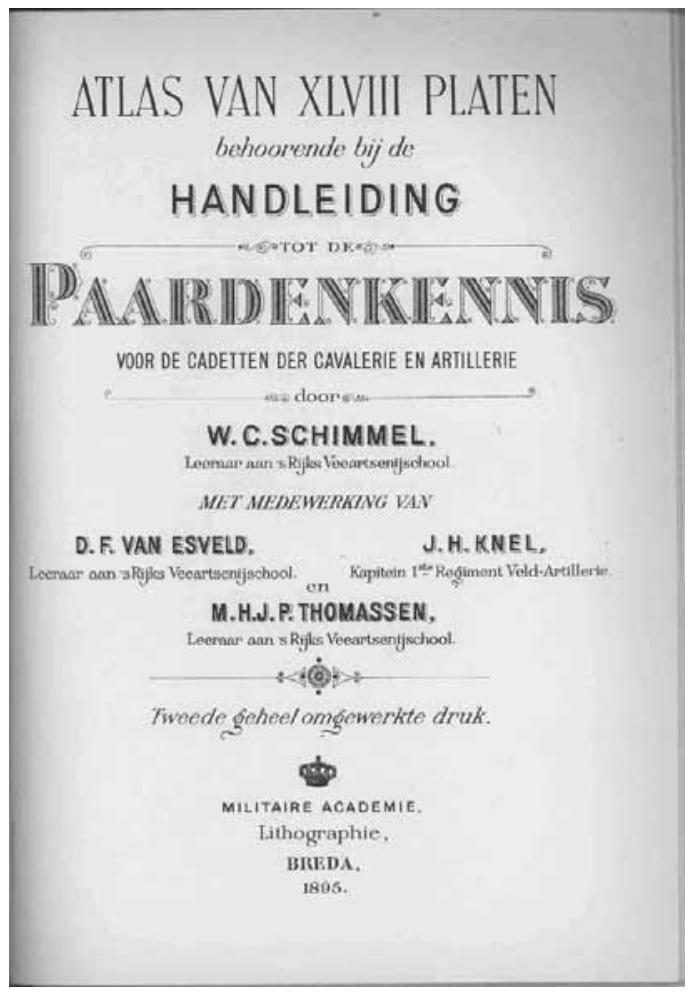

Fig. 1 Handbook on equitation for the cadets of the cavalry and artillery by W. C. Schimmel, teacher at the "Rijks Veeartsenijschool" 1895.

Handbuch über Reitkunst für Kadetten der Kavallerie und Artillerie von W. C. Schimmel, Lehrer die Reichs-Tierarztschule 1895.

Although the equine vets had a certain status, the veterinary profession in general was not held in high esteem. Due to shortages of the Agricultural Fund, the number of students decreased and the average income of veterinarians was low, which was of course an uninviting prospect for the students. These were mainly children of teachers, veterinarians, government officials and farmers. Children of the higher social classes were trained as naval officers, general physicians, or surgeons, educations with a more prosperous future (Offringa 1983, Wester 1939). 


\section{Equine veterinary care 1914-1945}

The number of horses in The Netherlands increased between 1871 and 1900 (Figure 2). In August 1914 the First World War broke out and many veterinary students were called into active service (Offringa 1971). The Netherlands remained neutral during the entire war, but the armed forces remained mobilised throughout and during the war about 100 military equine veterinarians were active, while during peace time only 28 used to be employed. On March 2nd 1918 the "Rijksveeartsenijschool" became an institution of higher education called the "Veeartsenijkundige Hoogeschool" (Veterinary College) by Royal Decree. Only seven years later, in 1925, the "Veeartsenijkundige Hoogeschool" lost its independent status and became the Veterinary Faculty of Utrecht University (founded in 1636), mainly for economical reasons (Offringa 1981, Offringa 1971, Wester 1939).

Common equine veterinary skills at the end of the nineteenth and beginning of the twentieth century and important equine diseases that give an idea of the state of the art in those days include: hoof diseases (Hartog 1912a), diagnosis of podotrochleosis, neurectomy, embryotomy, influenza, malleus (glanders), scabies, exanthema coitale, intoxication by fungi, botulism, strangles, abortion, bacteriology and parasitology. Disinfection of wounds and bandages with iodine became standard and general anaesthesia of horses with chloral hydrate and local anaesthesia with cocaine, later supplemented by regional nerve blocking with novocaine, enhanced the development of surgery. Radiography, invented in 1895, was soon to be used in veterinary medicine as well, but it took until after the Second World War before it was used in horses in the Netherlands (Frederik and Zantinga 1960). In 1898, torsion of the colon was diagnosed rectally and treated by turning over the horse. For the first time antipyretic agents like acetyl salicylic acid were used (Offringa 1981, Wester 1939). At the beginning of the twentieth century the first "chemotherapeutics", starting with salversan and neosalversan (1910), were introduced. The "travail bascule" was invented, enabling new surgical techniques for instance for the treatment of laryngeal hemiplegia (Hartog 1912b, Hartog and Loran 1919), and crib-biting (Hartog 1921). Also, strongyloides infestation was identified in faecal samples at the Veterinary Faculty in Utrecht by J. Wester (strongyloides Westeri) and laminitis and haemoglobinuria were described as sequels to the feeding of beetroots.

At this time, the veterinary education and profession in the Netherlands started to reach a level that, for the first time, met international standards. The World Veterinary Association met in the Netherlands for the first time in 1909. Veterinary science was flourishing, cattle breeding, animal production and meat and milk hygiene asked for more veterinarians. This increased demand led to a shortage of veterinarians and gave these a position where they could claim a better social and financial position. Local governments were paying extra allowances for veterinarians settling in their province (Wester 1939). Agriculture was booming business, but with the increasing motorisation of traffic after the invention of the combustion engine, horses became less frequent in the cities and on the roads.

The position of the veterinarian was secured and acknowledged through legislation on veterinary education (1874,
1917), meat inspection (1919) and by the act on livestock (1870, 1907, 1920). Finally, the "empirical medicine" as practiced by laymen was losing ground; this was in part also due to the work of the "Maatschapii ter Bevordering van de Veeartsenijkunde en Veeteelt in Nederland" [Society for the improvement of veterinary medicine and livestock breeding in the Netherlands], established in 1862, and to the publication of the "Veeartsenijkundig Magazijn" [Veterinary Magazine, from 1827-1847] and the "Tijdschrift voor Veeartsenijkunde en Veeteelt" [Journal of Veterinary Medicine and Livestock Breeding, from 1863-1915]. Even though motorised transport increased between the two World Wars, the number of equine veterinarians increased from 55 in 1926 to 87 in 1940 (Offringa 1981). These were all male vets because at first all students at the veterinary faculty were of the male gender. However, in 1925 the first female student (who would not pursue an equine career) entered the veterinary curriculum (Offringa 1981).

The number of horses used in agriculture decreased between 1921 and 1937, but increased again in the years thereafter. The use of sport horses became more common, though still limited to the upper class and hence absolute numbers were limited. The capitulation of The Netherlands in May 1940 and the mechanisation of the armed forces when these were reconstituted after the end of the German occupation meant the end for the military veterinary services and thus for the military equine veterinarians (Mossel and Koolmees 2003).

\section{The post war period}

Until the 1960s more cattle than horses were treated at the Veterinary Faculty due to the diminishing importance of the horse in agriculture, but the number of equine patients increased at the end of the sixties because of the upcoming equestrian sports and use of the horse for recreation (Figure 2) (Offringa 1981). From 1963 onwards the economy in the Netherlands started to flourish and, with the support of the

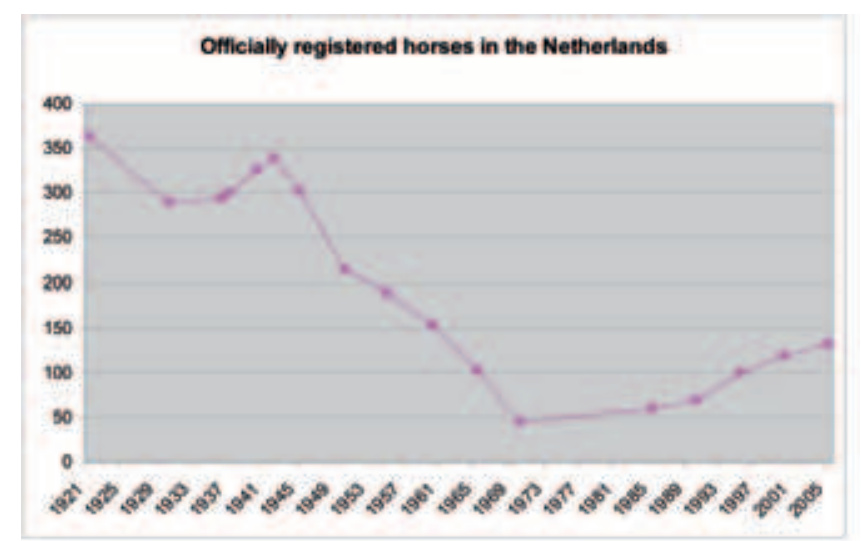

Fig. 2 Officially registered horses in the Netherlands (Offringa 1971, Offringa 1981, Statline 2008, PVE 2008). Numbers refer to horses officially registered for the military and on farms. At this moment $(2008)$ the total number of horses in the Netherlands is estimated 440,000.

Offiziell registrierte Pferde in Holland (Offringa 1971, Offringa 1981, Statline 2008, PVE 2008). Die Zahlen beziehen sich auf offiziell registrierte Militär- und Landwirtschaftspferde. Aktuell (2008) wird die Gesamtpferdezahl in den Niederlanden auf 440.000 geschätzt. 
Minister for Education Cals, plans to build a completely new veterinary faculty at another location could be made. The first clinic on the newly built university campus "De Uithof", east of Utrecht was the Institute for Reproduction and Obstetrics, which was officially opened in October 1967 by HRH Prince Bernhard.

The clinic for General and Large Animal Surgery followed in 1968, Large Animal Medicine in 1969, and Companion Animals in 1970. The facilities were "state of the art" and unprecedented with respect to size and equipment. At that moment the dividing lines in the clinical departments followed the disciplines, not the species. Only the clinic for Companion Animals encompassed all disciplines (except for reproduction and obstetrics). The three large animal departments all received horses. Frequently encountered patients were colic horses (Numans 1953), chronic respiratory diseases (heaves), metabolic problems such as hyperlipaemia and laminitis, horses with tetanus, and ataxia. Numbers of horses decreased until 1965, but increased after that to 2400 per year, enough for teaching and research purposes (Offringa 1981). New techniques were applied to horses such as epidural anaesthesia, caesarean section, taking of endometrial biopsies and uterine swabs, artificial insemination (started in 1970). Also, equine stud fertility management was introduced (van Leeuwen 1973, Offringa 1981). At the Large Animal Surgery department the caseload existed of colic surgeries and other soft tissue surgeries such as operations for cribbiting, laryngeal hemiplegia, cryptorchidectomy, dental and other head surgery, and orthopaedic cases. A great leap forward was the introduction of inhalation anaesthesia (Numans and Lagerweij 1963, Offringa 1981). The increased interest in equine medicine and surgery also boosted horse-related research. Research topics included gait analysis, biomechanics and osteoarthrosis. There was international recognition for these clinical, educational and scientific achievements of the Veterinary Faculty. In 1973, a combined team of the Council on Education of the American Veterinary Medical Association (AVMA) and the National Examining Board of the Canadian Veterinary Medical Association (CVMA) paid an accreditation visit to Utrecht University. As a result the Veterinary Faculty of Utrecht University became the first faculty outside North America to obtain full accreditation. Since then visits have been made in 1978, 1985, 1992, 2000 and 2007 and the accreditation has been maintained after every visit (van Beukelen 2007).

\section{Revival of equine veterinary care}

Veterinary attention dedicated to horses in the second part of the twentieth century was not associated with the military anymore, but with the breeding, examining, training and treatment of sport and leisure horses. This new position of the horse, leading (again) to an increasing economic importance of the equine sector, was acknowledged by the government and breeding organizations. At that time the craftsmanship of the Dutch farmers in breeding cattle, poultry and pigs resulted in a flourishing agro-industrial complex, facilitated by regulations and subsidies of the European Union. The existing knowledge and institutions were slowly but surely also made available for the equine species and funds were dedicated to do research at government owned equine field stations in col- laboration with the Veterinary Faculty and Wageningen Agricultural University. This resulted in popular and scientific publications on equine housing, feeding, exercise and training, fertility, osteochondrosis, pre-purchase examinations and the clinical significance of radiographic findings, the latter being of great help for the Dutch equine studbooks with their selection of sires and dams.

These developments did however not change the veterinary curriculum at the time. This remained a single track curriculum aiming at the formation of the classic "omnipotent" vet. Meanwhile, out in practice there was a growing demand from horse owners, cattle breeders, pig farmers, companion animal owners etc. for veterinarians with more specific knowledge on the species they were interested in and self-educated and unofficially specialised equine vets started to be recognised. Only a few veterinarians responded to this new market demand and they were the equine veterinary pioneers from the postwar period, ahead of their time. It took a long time before the Royal Veterinary Association of The Netherlands and the Veterinary Faculty responded to these de facto changes (Offringa 1981). This had more to do with clinging to old-fashioned concepts by the Association than with a lack of knowledge on the equine species at the Faculty where equine research started to boom in the late 1970s and early 1980s. Much research was done on the growing equine patient populations of the clinical departments (Kalsbeek 1970, Dik et al. 1978, Barneveld 1981, Wagenaar 1983, Kersjes $1983 a$ and b, Merkens and Rutgers 1983, Wagenaar and Kroneman 1986, Bos et al. 1986,), but especially in those days students were kept at a safe distance and not often allowed to give an intravenous injection, castrate a horse, apply local anaesthesia or inject a joint (Offereins 2000, Offereins and den Hartog, personal communications 2008). Therefore, after obtaining the general qualification to practice veterinary medicine, the practitioners who wanted to specialise in equine medicine had to educate themselves further in practice by reading (foreign) equine veterinary journals, visit (foreign) equine practitioners and share experiences, extrapolate knowledge from other species and of course by trial and error.

Specific equine therapeutics where scarce and colic surgery was initially only performed at the university clinic, with often disappointing results. This was at least partially due to the fact that horses used to be referred at a very late stage, often even moribund. On the other hand practitioners and owners were discouraged by the results of colic surgery and tried to avoid or postpone surgery as much as possible, leading to a vicious circle that was hard to break. When finally the horses were sent in at an earlier stage, the outcome of (surgical) intervention improved dramatically, which enhanced the mutual understanding between the referring equine practitioner and the Faculty. In the 1980s and 1990s colic surgery stated to be provided as a service in some practices in the Netherlands and across the border in Germany, where the equine veterinary pioneers of that period faced this challenge because of personal interest or forced by their geographic position that precluded timely referral. Slowly but surely these selfmade equine practitioners established well known equine practices throughout the country, gaining expertise from their increasing caseload and driven by their enthusiasm, eagerness to learn, will to travel, and dedication to the equine species. 
Sophisticated facilities with respect to diagnostic imaging, inhalation anaesthesia, operating theatres, mobile and adjustable operating mattresses, osteosynthesis, arthroscopy, endoscopy, artificial insemination, ultrasonography and embryo transplantation became gradually available at these practices (Loomans et al. 2007).

\section{Organising equine veterinary care in the twentieth century.}

The changing position of the horse in Dutch society was recognised in the early seventies by some equine specialists among the staff members of the Veterinary Faculty. Professor G. Wagenaar from the department of Large Animal Medicine, together with Dr. F. Németh from Large Animal Surgery and two practitioners, F. v.d. Veen DVM and P. den Hartog DVM, established the "Nederlandse Vereniging voor Paardenpractici" [Dutch Association of Equine Practitioners] in 1971, which society still exists to date as "Groep Geneeskunde van het Paard [Society for Equine Veterinary Medicine]. From the start, this association has always included both practitioners and staff members of the Veterinary Faculty. This group of equine veterinarians provides an identity to those involved in the treatment of horses and acts as a platform and network for equine veterinary healthcare.

Already in 1966 a discussion started between the veterinary faculty and the Royal Veterinary Association of the Netherlands about differentiation (tracking) within the curriculum, but these talks remained without results (Offringa 1981). In Europe there was agreement that the single diploma and general competence of the veterinarian had to be maintained. However, specialisation after graduation was generally accepted and acknowledged by the European Union in Wiesbaden in 1972 (Offringa 1981). In the Netherlands, the specialisation was organised by the Royal Veterinary Association of the Netherlands. Regulations for the acknowledgement and registration of veterinary specialists were written and an official registration committee was installed (Anonymous 2008). Fields for equine specialisation were internal medicine, reproduction and surgery. Diagnostic imaging became a cross-species specialisation. Beginning in the 1990s, equine practitioners who had ample expertise and a proven track record in one of these disciplines were encouraged to apply for a "de facto" recognition; they would form the founding fathers of the new specialisations. Specialists were supposed to spend at least $50 \%$ of their time working in the field of their specialty and had to prove this by maintaining a case log. Further, they had to apply for reaccreditation every five years. Training as an equine specialist was only possible while working at a clinic with more specialists and a caseload that was big enough. As a consequence, nearly all new specialists were educated at the Veterinary Faculty, introducing the, until then unknown, phenomena of equine internships and residencies, and increasing the need for more cases. Eventually, the entire structure of the large animal clinical departments was changed, not only because of the demand for speciesoriented specialisation, but also because both the veterinary profession and the Veterinary Faculty sensed a changing demand from their stakeholders. In 1992 the Dean of the Veterinary Faculty appointed a committee to write a strategy report for the Veterinary Faculty for the foreseeable future, thereby taking into account the changes in the profession. The committee believed that the time was now ripe to introduce a species-related tracking system in the veterinary curriculum that would provide the students with a better starting competence for one or more specific species (companion animals, farm animals, horses), while maintaining the general qualification (Anonymous 1994). In fact, it was a kind of comeback of the "equine veterinary officer first class", this time not requested by the Ministry of War (that in the meantime had be renamed as Ministry of Defence), but by the present-day stakeholders in the equine industry: owners, breeders, insurance companies, etc. The new curriculum started in 1995 with so-called mono tracks dedicated to a single species, but still contained combined tracks such as companion animals and equine, or bovine, porcine and equine. In 1999 the Veterinary Faculty moved from a discipline-oriented organisation to a species-oriented organisation and the Department of Equine Sciences was created, including all equine activities from the old surgery, medicine and reproduction clinics. Some years later funds were made available to rebuild and extend the old surgical clinic in order to create an equine hospital for all disciplines, which was officially opened in November 2007 by the Minister of Agriculture (Figure 3).

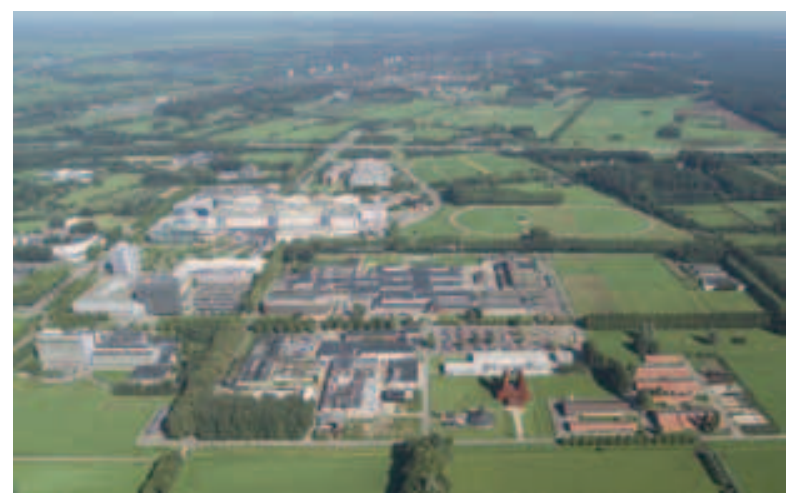

Fig. 3 Faculty of Veterinary Medicine, "De Uithof" in 2008. (Faculteit Diergeneeskunde, Afdeling Multimedia, Lisanne van der Voort) Ausdehnung der Tierärztlichen Fakultät "De Uithof" im Jahre 2008

\section{Contemporary equine veterinary care}

When Europe followed the US in establishing colleges for equine veterinary specialists, it was decided that from 2003 onwards registration as a specialist in the Netherlands should imply a European diploma for those specialisations that were covered by European colleges (Lumeij and Heritage 2006). Some Dutch specialists made the effort to become a European diplomate, but most specialists, especially those who worked outside the Veterinary Faculty in private practices, decided to stick to the Dutch title, which was very well accepted by horse owners, insurance companies and equine veterinarians.

At that time the private equine practices in the Netherlands were not yet ready for the specialists and only one third was employed in practice (Table 1.). In this period much of the work we nowadays would call specialist work was done by self-educated equine practitioners from the first hour. They had "conquered" this position through a continuous investment in self-development that brought no title, but yielded knowledge and skills that were widely recognised and respec- 
Table 1 Working environment of equine specialists registered in the Netherlands (Anonymous 2003). / Arbeitsumfeld in Holland gemeldeter Pferdeärzte (2003)

\begin{tabular}{lccccc}
\hline & Practice & Faculty & Not practicing & Job abroad & Total \\
\hline Diagnostic imaging & 2 & 2 & & 1 & 5 \\
Equine reproduction & 9 & 1 & 1 & 2 & 13 \\
Equine internal medicine & 3 & 6 & 6 & 2 & 17 \\
Equine surgery & 7 & 11 & 9 & 6 \\
\hline
\end{tabular}

ted (Loomans et al. 2007). Already in 1988 the Veterinary Faculty did marketing research on the employment of veterinarians (van Dijk and de Vries 1988). Recommendations concerning the curriculum were the introduction of more diversity in the education, which included species-oriented tracks. Further, for practice, the development of larger multivet practices with species-dependent sections was recommended. The veterinary profession received the advice to implement quality systems for practices and also for (speciesspecific) veterinarians, in order to make quality of care recognisable. As said earlier, tracking in the veterinary curriculum started in 1995 and the Royal Veterinary Association of the Netherlands started to work seriously on a quality system for veterinary practices embedded in a standardised ISO system and a species-specific system of acknowledged veterinarians. The agro-industrial complexes in the farm animal sector requested these acknowledgements for their quality systems in the food chain. Equine veterinarians, studbooks and equine insurance companies believed it to be a good and transparent quality system for equine practice too and added a quality system for pre-purchase examinations and examinations for selection of breeding stock (VKO 2002, 2003, de Groot and de Ruiter 2004). In neighbouring European countries similar systems for acknowledged equine veterinarians (separate from European specialists) were introduced such as the "Vakdierenarts Paard" in Belgium, "Fachtierarzt für Pferde" in Germany, "Spezialtierarzt FVH für Pferde" in Switzerland, and "Equine Board Certificates" in Great Britain. The response to the introduction of what was to be called the Acknowledged Equine Veterinarian in 2001 in the Netherlands was beyond expectations. For this certificate, equine practitioners needed to have at least two years of experience in equine practice, work at least 30 hours per week hands on with horses, and attend continuing education (CE) for at least 40 hours per year. Further, a basis course of three days had to be attended. There was a reassessment every two years. At the end of 2004, not less than 428 acknowledged equine veterinarians had been registered. Audits revealed that $23 \%$ of these had problems with the number of the hours hands-on and $17 \%$ failed with respect to the CE credits (Loomans 2004). An additional qualification was that of official pre-purchase examination vet, who was allowed to perform pre-purchase examinations for specific insurance companies and studbooks. Additional requirements for these vets included proof of adhering to an official protocol or the examination of horses for two years or more, adequate hardware and facilities and the protocols, including radiographs, of at least twenty examinations had to be available for reassessment by an official committee. At the end of 2004, 19 official pre-purchase examination vets had been registered. Practice certification according to an ISO protocol, was introduced step by step in this accreditation system. For the equine practitioners this was voluntary, but for farm animal species it was obligatory. This caused much upheaval in the normally relatively quiet and loyal veterinary profession and almost led to the dissociation of the Royal Veterinary Association of the Netherlands. The Association then sent all veterinarians a questionnaire on the subject (Voorsluis 2005). Based on the outcome, it was decided to dismantle the quality system. The obligation imposed by the Association changed into an appeal on the moral standards of the vets. The tragic end of the quality system was not welcomed by some stakeholders, in particular the insurance companies and the studbooks, which were happy with their qualified pre-purchase vets. They insisted on the reintroduction of this part of the system, which indeed has been effectuated at the end of 2007.

The introduction of the acknowledged equine vets originated a very positive momentum for the development of the equine veterinary profession. The basic courses were fully booked. In these, many subjects that were relevant for practice were discussed in-depth, indirectly creating consensus on the best approaches. The outcome of these discussions served as a basis for the establishment of professional guidelines that, once agreed upon, were published in the "Tijdschrift voor Diergeneeskunde" (Dutch Veterinary Journal). Guidelines were made on acute lameness, fertility, infectious diseases, colic, semen handling, rectal tears, foal diseases etc, which were also used in court cases (Sloet van OldruitenborghOosterbaan et al. 2003, Seuren-Coppens et al. 2003, van Schie and Barneveld 2003).

The introduction of the "Acknowledged Equine Veterinarian" was in line with the curricular development at the Veterinary Faculty. In 2001 the curriculum was renewed again. The trakking system was extended to the first four pre-clinical years, which consisted of a common core track for all students and a species-related part that started already in the first year. Further, here was more emphasis on the development of academic skills and on development of a professional attitude. The clinical education consisted of one general year for all students in which they rotated over all clinical departments and a final clinical year that was completely dedicated to one species or group of species, being farm animals, companion animals or horses. This curriculum aimed at more in-depth knowledge and skills in the direction of choice than a mere starting competence. Outcome criteria for the veterinary curriculum were defined in collaboration with the veterinary profession in the field and used as a yardstick for the quality of the curriculum (van Beukelen and van der Maazen 2006).

The importance of the equine species is clearly visible in the Dutch landscape where horses are outnumbering cattle in some places. Agriculture has intensified enormously over the 
past decades and has increased in scale thanks to technical developments and forced by worldwide competition. The small farms that were responsible for the initial growth of the agro-industrial complex are being abandoned by the older farmers, who are replaced by hobby farmers keeping horses, sheep and cattle for fun, recreation and competition, but not for earning a living. These horses however have to be bred, born, educated and taken care of, thus offering employment for a growing equine sector that has even outgrown Holland's famous flower bulb industry in economic importance. With an annual turnover of over two billion Euros the equine sector has become an industry in its own right and is attracting the attention of the government and investors (PVE 2008). On a population of sixteen million people, 456,000 persons (older than 8 years of age) have been riding a horse at least once a week for 5 years and 81,000 of them participate in equine competitions and events (Anonymus 2006). The Royal Netherlands Equestrian Federation has become the fifth sports federation of the country with 195,526 members in 2007 (KNHS 2008). The estimated number of horses in the Netherlands is 440,000 which are for almost 100\% sport and leisure horses (PVE 2008). Compared to the 364,000 horses in 1921, when horses were still almost exclusively used for transport, agriculture and the military and hardly for sport and leisure, this number is impressive. Of course these developments have consequences for equine veterinary healthcare. Compared to 87 equine veterinarians for 326,000 horses in 1940 (3,747 horses/vet), there are now 415 Acknowledged Equine Veterinarians (1,070 horses/vet). Despite the fact that the underlying care quality system has ceased to exist, the title of Acknowledged Equine Veterinarian is still widely used and people tend to maintain their registration by paying an annual registration fee. Certified equine pre-purchase examination veterinarians increased in number from 19 in 2004 to 45 in 2008. The maintenance of this title requires a minimum number of cases per year (Stichting paard 2008). The number of registered equine specialists in the Netherlands at the end of 2007 with a Dutch or international diploma was 88: internal medicine 25, surgery 35, reproduction 15 and diagnostic imaging 13. At the moment there are 1324 veterinary practices in The Netherlands, of which 252 employ Acknowledged Equine Veterinarians and/or Equine Pre-purchase veterinarians and/or a registered Equine Specialists (Anonymous 2008).

\section{Conclusions}

This study has tried to picture the role of the providers of equine healthcare against the background of the developing veterinary profession from the cradle, when equine healthcare was an important strategic military item and instrumental in the establishment of veterinary schools throughout Europe, to the present situation where specific equine veterinary medicine is back on stage and is again seen as an important part of the veterinary profession.

There is a strong demand from the clients for specific equine healthcare and some vets have strong personal interests in the sector. This ongoing differentiation is formalised and facilitated by the veterinary profession through the introduction of acknowledged equine veterinarians, equine pre-purchase examination veterinarians and board certified equine specia- lists. Also, the introduction of the equine track in the veterinary curriculum and equine residencies and internships provide veterinarians with an equine profile. This is not an exclusive Dutch development. There is worldwide increasing interest in horses and equine medicine, as can witnessed by many international journals on equine veterinary practice, a large offer in international continuing education on equine healthcare and the existence of many national and international equine veterinary organizations.

Speaking strictly legally the equine vet does not exist as a separate profession, because there is only a single and general diploma. Indeed, some professionals practicing equine veterinary medicine still treat other species as well (Loomans et al. 2007) and vice versa since they are allowed to do so by law. However, societal changes and client demand have created a de facto equine vet and make the number of practices and practitioners working solely with horses still grow. It can be said, therefore, that the equine vet is back on the veterinary stage after a period of absence, in a position that is recognised and appreciated by the stakeholders and the veterinary profession itself.

\section{References}

Anonymous (1994) Diergeneeskunde in 2000; een studie met aparte studierichtingen. Een startnotitie over de toekomst van de Faculteit der Diergeneeskunde. Faculteit der Diergeneeskunde. Utrecht

Anonymous (2003) Diergeneeskundig Jaarboek 2003. Koninklijke Nederlandse Maatschapij voor Diergeneeskunde, Utrecht

Anonymous (2006) Paardensportonderzoek 2006; Profiel, gedrag en behoeften Nederlandse paardensporters. ZKA Consultants \& Planners i.o.v. de Koninklijke Nederlandse Hippische Sportfederatie, Ermelo

Anonymous (2008) Diergeneeskundig Jaarboek 2008. Koninklijke Nederlandse Maatschappii voor Diergeneeskunde, Utrecht

Barneveld A. (1981) Einzelne klinische Aspekte des Spates und insbesondere die Arthrodese. Prakt. Tierarzt. 62, 608-610

Beukelen P. van (2007) Self Study Report Faculty of Veterinary Medicine. Faculty of Veterinary Medicine, Utrecht

Beukelen P. van and Maazen W. G. G. M. (2006) Program Outcomes of the Veterinary Curriculum. Faculty of Veterinary Medicine, Utrecht

Bos H., Meij van der G. J. W. and Dik K. J. (1986) Heridity of navicular disease. Tijdschr. Diergeneeskd. 111, 490-494

Cour P. A. van (1688) Toevlugt of Heylsame Remedien voor alderhande Siecktens en Accidenten die de Paerden soude konnen overkoomen

Dijk van C. and Vries de B. (1988) Arbeidsmarktonderzoek voor veterinair opgeleiden; Eindrapport. Instituut voor Toegepaste Sociale Wetenschappen, Nijmegen

Dik K. J., Németh F. and Merkens H. W. (1978) Radiologische klinische beschouwingen betreffende podotrochleose. Tijschr. Diergeneeskd. 103, 788-797

Frederik G. H. and Zantinga Jr. J. W. (1960) Rontgendiagnostiek en veterinaire praktijk. Diergeneesk. Memorandum 7, 1-43

Groot de S. J. and Ruijter de T. (2004) Quality control of the private veterinary profession in the Netherlands. Rev. sci. tech. Off. Int. Epiz. 23, 175-185

Hartog J. H. (1912a) De operatieve behandeling van straalkanker. Tijdschr. Veeaartseniik. 39,.

Hartog J. H. (1912b) Operatieve behandeling tegen Cornage volgens Williams. Tijdschr. Veeaartsenijk. 39,

Hartog J. H. and Loran G. J. (1919) De travail-bascule en haar gebruik. Tijschr. Veeaartenijk. 46,

Hartog J. H. (1921) De operatie tegen kribbebijten volgens Forssell. Tijdschr. Diergeneeskud. 48, 252-258 
Kalsbeek H. C. (1970) Koliek bij het paard. Tijdschr. Diergeneesk. 95, 429-437

Kersjes A. W. (1983a) De castratie. Tijdschr. Diergeneeskd. 108, 703-704

Kersies A. W. (1983b) Die Ankaufsuntersuchung, insbesondere die Bedeuting der Röntgenaufnahmen. Prakt. Tierarzt. 64, 189-192

KNHS (2008) Koninklijke Nederlandse Hippische Sportbond. www.knhs.nl

Koolmees P. A. (1992) De professionalisering van het veterinaire beroep in Nederland. Argos 6, 151-159

Koolmees P. A. (2000) Van paardendoctor-koemeester tot veterinary manager; regulering van de veterinaire markt in historisch perspectief. Argos 22, 75-77

Leeuwen van W. (1973) Het drachtigheidsonderzoek bii de merrie. Tijdschr. Diergeneeskd. 98, 483-491

Le Franca van Berkhey J. (1769) Natuurlijke Historie van Holland, vierde deel; Het Paard. Amsterdam 1769. Heruitgave Uitgeverii Ploegsma Amsterdam 1975

Loomans J. B. A. (2004) De erkende paardendierenarts; de huidige stand van zaken. Najaarsvergadering Groep Geneeskunde Paard 18 november 2004

Loomans J. B. A., Stolk P. W. Th., Weeren van P. R., Vaarkamp H. and Barneveld A. (2007) A survey of the workload and clinical skills in current equine practices in The Netherlands. Equine vet. Educ. 19, 162-168

Lumeij J. T. and Herrtage M. E. (2006) Veterinary Specialization in Europe. Journal Vet. Medic. Educ. 33, 176-179

Merkens H. W. and Rutgers L. J. E. (1983) Een inventarisatie van de castratie van de hengst aan de hand van een enquete gehouden onder Nederlandse dierenartsen. Tijdschr. Diergeneeskd. 108, 712-717

Mossel en Koolmees P. A. (2003) Veterinairen in militaire dienst. Argos 29, 425-433

Naaldwijck van P. (1631) De Paardenvriend; over de natuur, het uitkiezen, het opvoeden, de africhting en de geneeskundige behandeling van paarden. Leiden 1631. Vertaling plus inleiding door Berns J.B., Oosterhuis A.C., Mathijsen A. Erasmus Publishing Rotterdam 1995

Numans S. R. (1953) De maagdarmchirurgie bij paard en rund. Rede vitgesproken bij de aanvaarding van het ambt van hoogleraar in de veterinaire heelkunde aan de Rijksuniversiteit te Utrecht, op 23 Maart 1953. Tiidschr. Diergeneeskd. 78, 546-559

Numans S. R. and Lagerweij E. (1963) Inhalatienarcose bij de grote huisdieren. Tijschr. Diergeneeskd. 88, 1789-1795

Offereins E. (2000) Paardengeneeskundige ontwikkelingen in de 20e eeuw. Tijdschrift voor Diergeneeskunde 125, 560-563

Offringa C. (1971) Van Gildestein naar Uithof; 150 jaar diergeneeskundig onderwijs in Utrecht Deel I. Rijksuniversiteit Utrecht, Faculteit der Diergeneeskunde 1971. p. 7-78, 166, 232

Offringa C. (1981) Van Gildestein naar Uithof; 150 jaar diergeneeskundig onderwijs in Utrecht Deel II. Rijksuniversiteit Utrecht, Faculteit der Diergeneeskunde 1981. p. 25, 40, 184, 236-242, $367,368,379-387,395,398$
Offringa C. (1983) Ars Veterinaria: ambacht, professie, beroep. Sociologische theorie en historische praktijk. Tijdschrift voor Geschiedenis 96, 407-432

P.V.E. (2008) www.pve.nl Production board for livestock, meat and eggs. Den Haag.

Schie J. T. M van and Barneveld A. (2003) Leidraad paard: acuut kreupel. Tijdschrift voor Diergeneeskunde 128, 449-452

Schimmel W. C., Esveld van D. F., Knel J. H. and Thomassen M. H. J. P. (1895) Handleiding tot de Paardenkennis voor de Cadetten der Cavalerie en Artillerie (Handbook on equitation for the cadets of the cavalry and artillery) Militaire Academie Breda 1895, second edition. p. 717-751

Sloet van Oldruitenborgh-Oosterbaan M. M. and Jacobs P. H. M. M. (2003) Leidraad paard: acute koliek. Tijdschrift voor Diergeneeskunde 128, 446-448

Seuren-Coppens M. L. G., Parlevliet J. M., Stout T. A. E. and Weijden G. C. van der (2003) Leidraad paard: fertiliteit merrie. Tijdschrift voor Diergeneeskunde 128, 443-445

Statline (2008) Centraal Bureau voor de Statistiek. Voorburg/Heerlen

Steltenpool B. A. (1996) Dienaren van Aesculaap en Mars; De militaire dierenarts in Nederlands Oost-Indië. Scriptie Faculteit Diergeneeskunde Universiteit Utrecht

Stichting paard (2008) www.stichtingpaard.nl Lijst van erkende keuringsdierenartsen paard

Voorsluis J. G. (2005) KNMvD ledenraadpleging inzake erkenningen en praktijkcertificering; Eindrapport. Koninklijke Maatschappii voor Diergeneeskunde, Houten

VKO (2002) Praktijkmap Kwaliteitsrichtlijnen. Veterinair Kwaliteitsorgaan. Houten

VKO (2003) Jaarbericht 2003. Stichting Veterinair Kwaliteitsorgaan. Houten

Wagenaar G. and Kroneman J. (1986) Cardiovascular diseases. Equine diseases (edited by H.J. Wintzer) p 47-88. Paul Parey. Berlin.

Wagenaar G. (1983) De keuring van het paard. Eerste druk. Wetenschappelijke vitgeverii Bunge. Utrecht

Wester J. (1939) Geschiedenis der Veeartsenijkunde. Utrecht. p. 142 $-151,157-160,193,252-281,319-323,450-451,453$

Joop B. A. Loomans

Department of Equine Sciences

Faculty of Veterinary Medicine

Utrecht University

Yalelaan 174

3584 CM Utrecht

The Netherlands

i.b.a.Loomans@uu.nl 